\title{
Breaker of chains
}

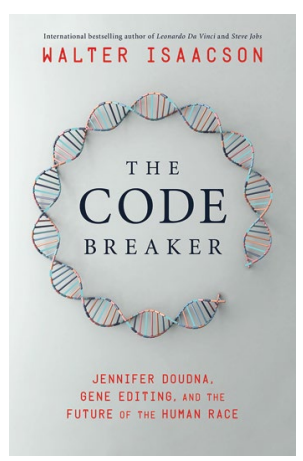

The Code Breaker: Jennifer Doudna, Gene Editing, and the Future of the Human Race By Walter Isaacson

Simon \& Schuster (2021) US\$35

n time-honoured tradition, the UC Berkeley biochemist Jennifer Doudna received her Nobel Prize wake-up call in the middle of the night. More unusually, the caller had an English accent. Doudna, having slept through the official call from Stockholm, was awakened by a diligent Nature reporter seeking her reaction following the public announcement of the 2020 Chemistry prize.

The development of clustered regularly interspaced short palindromic repeats (CRISPR) had been widely tipped for a Nobel Prize despite a bitter protracted patent feud over the breakthrough gene editing technology. In the end, the 2020 Nobel Prize in Chemistry was shared by Doudna and French microbiologist Emmanuelle Charpentier, rewarding a collaboration forged on the streets of San Juan, Puerto Rico, in early 2011. Fifteen months later, in what gene editing pioneer Fyodor Urnov hailed as an "immortal" paper in Science, Doudna and Charpentier laid the foundation for a genome editing revolution.

The 'CRISPR craze' has spawned myriad applications in medicine, agriculture and basic research, prompting countless magazine cover stories, books and films, ranging from an award-winning documentary to a preposterous sci-fi blockbuster starring The Rock. And now it has inspired the latest page-turning tale from historian and former TIME editor, Walter Isaacson.

The author of best-selling biographies of Da Vinci, Einstein and Steve Jobs, Isaacson weaves a riveting story of science, biotechnology,
RNA and CRISPR, with Doudna taking centre stage. Doudna was an elite scientist before she got smitten by the CRISPR bug: she trained with two chemistry Nobel laureates (Jack Szostak and Tom Cech) and was named an investigator of the Howard Hughes Medical Institute. She had co-authored some 20 'CNS' (Cell/Nature/Science) papers when she met Charpentier in 2011.

The seminal work of Doudna and Charpentier was built on a foundation 35 years in the making. Discoveries made in Japan and Europe described peculiar DNA repeat regions in bacteria and archaea, before three groups more or less simultaneously tied their function to that of an anti-viral immune system. This was proven experimentally in 2007 by a team at Danisco, a yoghurt company of all places. Yes, without a functioning CRISPR system to combat phages, your pizza cheese and many other fine dairy products are in jeopardy.

Isaacson breezes through the early history of CRISPR without shirking some technical nitty gritty - from the significance of tracrRNAs to nuclear localization signals and codon optimization. He highlights the rivalries - not just the famous rift between Doudna and the Broad Institute's Feng Zhang but also among former colleagues. Charpentier, 'a reticent Parisian' now based in Berlin, comes to resent Doudna's elevated media profile (even though Doudna commendably took ownership of the CRISPR ethics debate) and her successful book A Crack in Creation. Doudna co-authored this with Sam Sternberg but it is written to Charpentier's dismay - in the first person. In a lovely scene, Isaacson reveals how he helped engineer a rapprochement between the two women.

While Doudna is the common thread, Isaacson's story travels along many tributaries. He spotlights younger researchers who are adding to the CRISPR toolbox and dabbles in some CRISPR experiments of his own (thankfully under the watchful eye of Doudna's postdocs). Later on, there is a detour to visit Jim Watson, recuperating from a serious car accident and other self-inflicted wounds, at his Cold Spring Harbor home. Like Doudna, Isaacson remembers being electrified reading a first edition of Jim Watson's classic book, The Double Helix. Given the dawning potential of CRISPR in treating diseases such as sickle cell disease, he hopes that "Zhang and [George] Church and perhaps David Liu will someday win the Nobel Prize for Medicine."

"We can steer a course that avoids a Promethean quest for controlling our own endowments while also avoiding complete submission to the vagaries of a lottery," Isaacson writes. "Wisdom involves finding the right balance."

In the closing section, Isaacson follows Doudna, Zhang and their colleagues as the CRISPR community pivots to tackle the COVID-19 crisis. Doudna inspired her troops to set up a PCR diagnostics lab from scratch, while the rivals set about developing the next generation of CRISPR-based diagnostic tools. Isaacson senses a more collaborative spirit between the rivals that will surely pay dividends come the next pandemic.

\section{Isaacson senses a more collaborative spirit between the rivals that will surely pay dividends come the next pandemic 5}

The Code Breaker is a true celebration of science and scientists, for all their flaws and jealousies. In a book of such scope, Isaacson skips over some key issues, especially the potential of CRISPR to help edit crop and livestock genomes to feed the planet, or tackle malaria using gene drives. But The Code Breaker will deservedly reach a huge audience unaccustomed to reading biographies of science celebrities or appreciating a microbial arms race as old as life on earth. Critically, it will raise the public understanding of CRISPR and the potential of genome editing for curing diseases, improving food production and vanquishing viruses.

\section{Reviewed by Kevin Davies}

Mary Ann Liebert, Inc., New Rochelle, NY, USA.

e-mail:kdavies@liebertpub.com

https://doi.org/10.1038/s41570-021-00274-5

\section{Competing interests}

K.D. is the Executive Editor of The CRISPR Journal.

\section{Further reading}

Davies, K. Editing Humanity: The CRISPR Revolution and the New Era of Genome Editing (Pegasus Books, 2020) 